\title{
Redistribution of adipose tissue found in type 2 diabetes mellitus
}

An ancillary study of the Look AHEAD (Action for Health in Diabetes) trial has found changes in adipose-tissue distribution that add to the literature on mechanisms that contribute to increased risk of insulin resistance in patients with type 2 diabetes mellitus (T2DM).

Obesity is a known risk factor for T2DM; however, clinicians remain uncertain whether patients with T2DM display a unique pattern of adipose-tissue distribution. Part of the problem in identifying differences in adipose-tissue distribution is that techniques such as dual-energy $\mathrm{X}$-ray absorptiometry cannot distinguish subcompartments of adipose tissue. In an attempt to overcome this limitation, the Look AHEAD investigators used wholebody MRI scans to compare adiposetissue distribution in individuals with and without T2DM.

Look AHEAD aims to prevent T2DMrelated cardiovascular disease by promotion of weight loss; however, participants enrolled in the ancillary study had not yet started the weight-loss intervention. Inclusion criteria were age $\geq 18$ years and BMI $\geq 25 \mathrm{~kg} / \mathrm{m}^{2}$ but $<38 \mathrm{~kg} / \mathrm{m}^{2}$. Total, subcutaneous, visceral and intermuscular adipose-tissue depots were measured by whole-body, multislice MRI. Subcutaneous adipose tissue was subdivided into lower leg, upper leg (femoral-gluteal), trunk and arm adipose-tissue depots.
The study group included 93 patients with T2DM (mean age 58.3 years, mean BMI $31.6 \mathrm{~kg} / \mathrm{m}^{2}$ ) and 93 unmatched, healthy control individuals (mean age 60.6 years, mean BMI $\left.29.6 \mathrm{~kg} / \mathrm{m}^{2}\right)$. All participants were of white or African American ethnic origin; both groups enrolled more women than they did men.

When compared with the control group, women with T2DM had less total adipose tissue; men with T2DM had more total adipose tissue. Patients with T2DM had less subcutaneous adipose tissue than their nondiabetic counterparts did; this difference was most pronounced in white patients with T2DM. Of note, patients with T2DM had less femoral-gluteal adipose tissue than did healthy individuals. The amount of visceral and intermuscular adipose tissue was greater in the T2DM group than in the control group.

Visceral and intermuscular adipose tissue are implicated in the development of insulin resistance. The findings of increased amounts of adipose tissue in these depots in patients with T2DM suggest a novel mechanism for insulin resistance in this group.

\section{Vicky Heath}

Original article Gallagher, D. et al. Adipose tissue distribution is different in type 2 diabetes. Am. J. Clin. Nutr. 89, 807-814 (2009). 